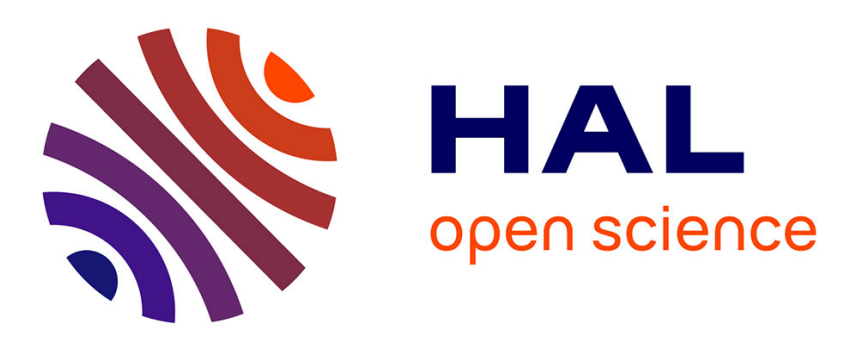

\title{
Brazing mechanisms of the Ti 2 AlC joints using a pure Al filler metal
}

Chengjie Lu, Liangbo Sun, Jie Zhang, Qin Qi, Gilles Hug

\section{To cite this version:}

Chengjie Lu, Liangbo Sun, Jie Zhang, Qin Qi, Gilles Hug. Brazing mechanisms of the Ti 2 AlC joints using a pure Al filler metal. Ceramics International, 2017, 43 (12), pp.8579-8584. 10.1016/j.ceramint.2017.03.113 . hal-01706603

\section{HAL Id: hal-01706603 https://hal.science/hal-01706603}

Submitted on 12 Feb 2018

HAL is a multi-disciplinary open access archive for the deposit and dissemination of scientific research documents, whether they are published or not. The documents may come from teaching and research institutions in France or abroad, or from public or private research centers.
L'archive ouverte pluridisciplinaire HAL, est destinée au dépôt et à la diffusion de documents scientifiques de niveau recherche, publiés ou non, émanant des établissements d'enseignement et de recherche français ou étrangers, des laboratoires publics ou privés. 


\title{
Brazing mechanisms of the $\mathrm{Ti}_{2} \mathrm{AlC}$ joints using a pure Al filler metal
}

\author{
Chengjie Lu ${ }^{1}$, Liangbo Sun ${ }^{1}$, Jie Zhang ${ }^{1 *}$, Qin Qi ${ }^{1}$, Gilles Hug ${ }^{2}$ \\ ${ }^{1}$ School of Materials Science and Engineering, Harbin Institute of Technology,
}

Harbin 150001, China

${ }^{2}$ Laboratoire d'Etudes des Microstructures, CNRS-ONERA,

Châtillon 92322, France

\begin{abstract}
Brazing of $\mathrm{Ti}_{2} \mathrm{AlC}$ ceramics has been successfully performed using a pure $\mathrm{Al}$ filler metal, in the temperature range $1023 \mathrm{~K}-1173 \mathrm{~K}$ and with holding time ranging from 0 min to $30 \mathrm{~min}$. The microstructure of the $\mathrm{Ti}_{2} \mathrm{AlC}$ joints was studied, and the mechanical properties of the joints were evaluated by shear strength test. It is observed that the Al filler has weak effect on the stability of $\mathrm{Ti}_{2} \mathrm{AlC}$ substrate, and only a small amount of decomposition products including the $\mathrm{TiC}_{\mathrm{x}}$ and $\mathrm{TiAl}_{3}$ compounds can be observed in the joints. In addition, the formation of an inter-diffusion layer in the $\mathrm{Ti}_{2} \mathrm{AlC}$ substrate is considered as the major brazing mechanism. The maximum shear strength of the $\mathrm{Ti}_{2} \mathrm{AlC}$ joints using the pure $\mathrm{Al}$ filler metal is $95 \mathrm{MPa}$, with an electrical conductivity of $2.21 \times 10^{6} \mathrm{~S} \cdot \mathrm{m}^{-1}$, after holding the sample at $1123 \mathrm{~K}$ for $10 \mathrm{~min}$.
\end{abstract}

\footnotetext{
* Corresponding author: Tel/Fax: +86 45186414234

E-mail address: hitzhangjie@ hit.edu.cn (J. Zhang).
} 
Keywords: $\mathrm{Ti}_{2} \mathrm{AlC}$; aluminum filler; brazing; mechanical property; electrical conductivity

\section{Introduction}

The MAX phases, which refer to a group of nanolaminate ternary ceramics with general formula $\mathrm{M}_{n+1} \mathrm{AX}_{n}(\mathrm{M}$, transition metal; $\mathrm{A}$, A-group element; X, carbon or nitrogen), have attracted increasing attention in recent years due to their unique combination of metallic and ceramic properties $[1,2]$. Among them, the $\mathrm{Ti}_{2} \mathrm{AlC}$ phase is one of the most fascinating members with typical 211 structure (i.e. $n=1$ ), since it possesses the lowest density of all compounds in this class [3], an excellent electrical conductivity [4] and a small friction coefficient [5]. Such characteristics qualify the $\mathrm{Ti}_{2} \mathrm{AlC}$ ceramics for many structural and functional applications as, for example, the heat/electron exchanger or high temperature solid lubricant. Numerous efforts have been carried out to synthesize $\mathrm{Ti}_{2} \mathrm{AlC}$ ceramics, via various techniques like combustion synthesis (CS) [6], spark plasma sintering (SPS) [7] and self-propagating high-temperature synthesis (SHS) [8]. However, it is still difficult to process dense $\mathrm{Ti}_{2} \mathrm{AlC}$ ceramics with high purity, large dimensions and complex shapes, because of the narrow single $\mathrm{Ti}_{2} \mathrm{AlC}$ phase domain in the $\mathrm{Al}-\mathrm{C}$ - $\mathrm{Ti}$ ternary phase system [9], which severely limits its applications. Joining technique is one of the convenient and promising solutions to overcome this problem. By achieving the $\mathrm{Ti}_{2} \mathrm{AlC}$ joints, the limitation of dimensions can be overpassed, and the component with complex shapes can be obtained by joining small bulks. 
Only few papers reporting about the joining of the MAX ceramics can be found in the past years, among which the diffusion bonding technique was mostly adopted. Inspired by the phenomenon that the MAX phases could form various solid solutions like (M, M')AX and M(A, A')X, Ganguly et al. [10] could successfully bond $\mathrm{Ti}_{3} \mathrm{SiC}_{2}-\mathrm{Ti}_{3} \mathrm{GeC}_{2}$ and $\mathrm{Ti}_{2} \mathrm{AlC}-\mathrm{Nb}_{2} \mathrm{AlC}$ couples using a direct diffusion method. Interestingly, they discover that the $\mathrm{Ti}_{3} \mathrm{SiC}_{2}-\mathrm{Ti}_{3} \mathrm{GeC}_{2}$ diffusion couple could form in the temperature range $1473 \mathrm{~K}-1773 \mathrm{~K}$, by forming a continuous gradient of $\mathrm{Ti}_{3}(\mathrm{Si}, \mathrm{Ge}) \mathrm{C}_{2}$ solid solutions. However, the diffusion temperature to obtain the $\mathrm{Ti}_{2} \mathrm{AlC}-\mathrm{Nb}_{2} \mathrm{AlC}$ couple was much higher, about $1723 \mathrm{~K}-1773 \mathrm{~K}$, which was mainly attributed to the strong M-X bonds in the MAX structure that need to break and reconstruct during the diffusion process. Similarly, Yin et al. [11] managed to join two samples of $\mathrm{Ti}_{3} \mathrm{AlC}_{2}$ ceramics by inserting a Si interlayer. The experiments were performed in the temperature range 1573 $\mathrm{K}-1673 \mathrm{~K}$, for $120 \mathrm{~min}$. The presence of a $\mathrm{Ti}_{3}(\mathrm{Si}, \mathrm{Al}) \mathrm{C}_{2}$ solid solution domain was confirmed by XRD, and a maximum flexural strength of the joints of $285 \mathrm{MPa}$, was obtained after holding the sample at $1673 \mathrm{~K}$ for $120 \mathrm{~min}$, accounting for $80 \%$ of the strength of the $\mathrm{Ti}_{3} \mathrm{AlC}_{2}$ substrate.

It can be concluded from the above analysis that extremely high temperature is required to achieve the MAX phase diffusion couple by forming solid solutions, which is considered to be even higher than the decomposition temperature of the ceramic substrate under vacuum [12]. To decrease the processing temperature, as well as to overcome some disadvantages of the diffusion technique, we have performed a study of 
brazing $\mathrm{Ti}_{2} \mathrm{AlC}$ ceramics using a pure $\mathrm{Ag}$ filler metal [13]. The results suggested that the silver filler could diffuse into the $\mathrm{Ti}_{2} \mathrm{AlC}$ substrate along the grain boundary, and then formed an $\mathrm{Ag}_{3}(\mathrm{Ti}, \mathrm{Al})$ solid solution in the interaction area. However, no $\mathrm{TiC}_{\mathrm{x}}$ compound, the typical decomposition product of the $\mathrm{Ti}_{2} \mathrm{AlC}$ ceramics, was detected in the XRD pattern, suggesting that the interaction effect between the silver filler and the $\mathrm{Ti}_{2} \mathrm{AlC}$ substrate would not induce a decomposition behavior of $\mathrm{Ti}_{2} \mathrm{AlC}$ ceramics [14]. Finally, the maximum shear strength of the $\mathrm{Ti}_{2} \mathrm{AlC}$ joints using pure Ag filler metal was measured to be $132 \mathrm{MPa}$, and was obtained for a brazing temperature of $1030{ }^{\circ} \mathrm{C}$ holding for $5 \mathrm{~min}$.

The goal of this work is to further decrease the brazing temperature of $\mathrm{Ti}_{2} \mathrm{AlC}$ ceramics, by using a pure $\mathrm{Al}$ filler metal. In addition, it is necessary to characterize the interaction behavior of the filler elements with the $\mathrm{Ti}_{2} \mathrm{AlC}$ substrate, to better understand the intrinsic structural features of MAX phases.

\section{Experimental procedure}

The bulk polycrystalline $\mathrm{Ti}_{2} \mathrm{AlC}$ selected in this study was processed by spark plasma sintering (SPS) using $\mathrm{Ti}, \mathrm{Al}$ and graphite powders. In general, minority phases, including the $\mathrm{TiC}_{\mathrm{x}}, \mathrm{TiAl}_{\mathrm{x}}$ and $\mathrm{Ti}_{3} \mathrm{AlC}_{2}$ compounds are always observed in $\mathrm{Ti}_{2} \mathrm{AlC}$ compounds, therefore, a detailed characterization of the raw material was performed. A backscattered electron (BSE) micrograph of the $\mathrm{Ti}_{2} \mathrm{AlC}$ substrate reveals its morphology as displayed in Fig. 1(a). Two phases with different contrasts can be observed. Firstly, the grey phase labeled $\mathrm{A}$ in the figure possesses an average atomic percentage of $\mathrm{Ti} 49 \%$, 
$\mathrm{Al} 24 \%$ and $\mathrm{C} 27 \%$ according to the EDS analysis. It is confirmed to be the $\mathrm{Ti}_{2} \mathrm{AlC}$ main phase. Secondly, the light phase labeled $\mathrm{B}$ is identified as the $\mathrm{TiAl}_{\mathrm{x}}$ intermetallic, with an average atomic percentage of $\mathrm{Ti} 72 \%$ and $\mathrm{Al} 28 \%$. Afterwards, an X-ray diffraction (XRD) characterization was performed, and the corresponding result is shown in Fig. 1(b). The major phase showing up in the XRD pattern is the $\mathrm{Ti}_{2} \mathrm{AlC}$ compound, and the minor phase is determined to be the $\mathrm{Ti}_{3} \mathrm{Al}$ compound, corresponding to the light phase $\mathrm{B}$ discovered in the $\mathrm{BSE}$ morphology. In order to obtain the $\mathrm{Ti}_{2} \mathrm{AlC}$ brazing joints with excellent heat/electron conductivity, the pure $\mathrm{Al}$ filler metal has been selected in the present work. In addition, the brazing filler with high $\mathrm{Al}$ content might be favorable for maintaining the stability of the $\mathrm{Ti}_{2} \mathrm{AlC}$ substrate during the brazing process, since the depletion of $\mathrm{Al}$ atoms in the $\mathrm{Ti}_{2} \mathrm{AlC}$ structure is considered to be the major cause of the decomposition behavior [15]. Although $\mathrm{Ti}_{2} \mathrm{AlC}$ joints brazed using a pure Al filler metal might not be applicable in many high-temperature areas, it is still a convenient way to achieve the $\mathrm{Ti}_{2} \mathrm{AlC}$ ceramic components which serve at room or intermediate temperature.

The bulk $\mathrm{Ti}_{2} \mathrm{AlC}$ ingots were cut into samples with dimensions of $4 \times 4 \times 4 \mathrm{~mm}^{3}$ for microstructural observation, and samples of $4 \times 4 \times 10 \mathrm{~mm}^{3}$ for shear strength testing and electrical conductivity test. The surface of the specimens was ground using the 800 -grit $\mathrm{SiC}$ paper, followed by the mechanical polishing using the $0.5 \mu \mathrm{m}$ diamond paste. Commercial pure Al foils $270 \mu \mathrm{m}$ thick were cut into pieces with dimensions of $4 \times 4$ $\mathrm{mm}^{2}$, and then etched in a $10 \mathrm{wt} . \% \mathrm{NaOH}$ solution and a 5 vol. $\% \mathrm{HNO}_{3}$ solution, to 
remove the native $\mathrm{Al}_{2} \mathrm{O}_{3}$ oxide scale. Afterwards, the $\mathrm{Al}$ foils were cleaned with water, and then preserved in ethanol. Two $\mathrm{Ti}_{2} \mathrm{AlC}$ rectangular specimens together with a pure $\mathrm{Al}$ foil were assembled in a sandwich structure: $\mathrm{Ti}_{2} \mathrm{AlC} / \mathrm{Al} / \mathrm{Ti}_{2} \mathrm{AlC}$, and then placed in a graphite jig, on which a constant load of $5 \mathrm{MPa}$ was applied to promote the contact of brazing filler with the ceramic substrates. A set of brazing experiments were performed under vacuum in a furnace, at brazing temperatures of $1023 \mathrm{~K}, 1073 \mathrm{~K}, 1123 \mathrm{~K}$ and $1173 \mathrm{~K}$, and holding times of $0 \mathrm{~min}, 10 \mathrm{~min}$ and $30 \mathrm{~min}$. A heating rate of $10 \mathrm{~K} \cdot \mathrm{min}^{-1}$ was used while a slower cooling rate of $5 \mathrm{~K} \cdot \mathrm{min}^{-1}$ was set in order to reduce the thermal stress in the joints that may form during the cooling period.

After the brazing experiments, shear strength tests were firstly conducted to obtain the optimal brazing parameters. The measurements were performed using a universal testing machine (Instron 5569) at room temperature, with a constant loading speed of $0.5 \mathrm{~mm} \cdot \mathrm{min}^{-1}$. Three samples were tested for each brazing parameter. Furthermore, a special designed jig was designed for this work [16] in order to minimize the influence of friction on the results of the tests: the jig was able to adjust the gap width accordingly. Considering the excellent conductivity of both the $\mathrm{Ti}_{2} \mathrm{AlC}$ substrate and the $\mathrm{Al}$ filler, the electrical conductivity of $\mathrm{Ti}_{2} \mathrm{AlC}$ joints at different brazing parameters was measured using the four-probe technique. The brazing mechanisms were analyzed by observing the morphologies and characterizing the phases in the joints. The morphology of the joints were investigated using a Sigma 500, Zeiss scanning electron microscope (SEM), which is equipped with an energy-dispersive spectrometer (EDS) to determine the 
elemental composition of the phases observed in the joints. In addition, the crystallographic structures of the bulk $\mathrm{Ti}_{2} \mathrm{AlC}$ substrate, as well as the phases in the joints, were characterized using an X'pert pro MPD, Panalytical X-ray diffraction (XRD) using the $\mathrm{CuK} \alpha$ radiation and steps of $0.05^{\circ}$ at a scanning rate of $5^{\circ} \cdot \mathrm{min}^{-1}$.

\section{Results and discussion}

\subsection{Shear strength test and electrical conductivity measurement}

Fig. 2(a) shows the shear strength of the $\mathrm{Ti}_{2} \mathrm{AlC}$ joints brazed at different temperatures. It can be observed from the diagram that the room temperature shear strength significantly improves with the rising processing temperature, from $46 \mathrm{MPa}$ at $1023 \mathrm{~K}$ to $85 \mathrm{MPa}$ at $1073 \mathrm{~K}$, and further increases up to $95 \mathrm{MPa}$ at $1123 \mathrm{~K}$. This improvement might be attributed to the reinforced interaction effect between the $\mathrm{Ti}_{2} \mathrm{AlC}$ substrate and the pure Al brazing filler: with the increasing brazing temperature, the wetting process, as well as the inter-diffusion or reaction process is promoted. However, when the brazing temperature reaches $1173 \mathrm{~K}$, the shear strength of the $\mathrm{Ti}_{2} \mathrm{AlC}$ joints declines to $75 \mathrm{MPa}$. The decreasing of mechanical properties at high temperature might be attributed to many factors, including a severe transformation of the ceramic substrate due to the changing phase equilibrium, the formation of continuous reaction products and the consumption of brazing filler in the joints. Overall, the optimal brazing temperature of the $\mathrm{Ti}_{2} \mathrm{AlC}$ joint is determined to be $1123 \mathrm{~K}$ in the present work. Fig. 2(b) shows the shear strength of the $\mathrm{Ti}_{2} \mathrm{AlC}$ joints brazed at the optimal temperature, with holding time of $0 \mathrm{~min}, 10 \mathrm{~min}$ and $30 \mathrm{~min}$, respectively. It can be concluded from the 
figure that extending the holding time results in a similar tendency whatever the brazing temperature is. When the holding time prolongs from $0 \mathrm{~min}$ to $10 \mathrm{~min}$, the shear strength of the $\mathrm{Ti}_{2} \mathrm{AlC}$ joints increases from $53 \mathrm{MPa}$ to $95 \mathrm{MPa}$, which may be attributed to the reinforced interaction effect as well; when the holding time further extends up to $30 \mathrm{~min}$, however, the shear strength decreases to $30 \mathrm{MPa}$. Overall, the optimal holding time is determined to be $10 \mathrm{~min}$ in this work. The microstructure is considered to have a significant effect on the mechanical properties of the joints. Therefore, a detailed observation of the morphology has been performed in the following sections to further illustrate how the microstructure evolution affects the shear strength of the $\mathrm{Ti}_{2} \mathrm{AlC}$ joints.

The electrical conductivity measurement results are also displayed in Fig. 2. Using the four-probe technique, the electrical conductivity of the $\mathrm{Ti}_{2} \mathrm{AlC}$ substrate in this work is measured to be $2.38 \times 10^{6} \mathrm{~S} \cdot \mathrm{m}^{-1}$, close to that reported in other works [17]. According to the diagrams, changing the brazing parameters has little effect on the electrical conductivity of the $\mathrm{Ti}_{2} \mathrm{AlC}$ joints: with the rising brazing temperature, the electrical conductivity increases from $2.12 \times 10^{6} \mathrm{~S} \cdot \mathrm{m}^{-1}$ at $1023 \mathrm{~K}$, to $2.23 \times 10^{6} \mathrm{~S} \cdot \mathrm{m}^{-1}$ and $2.21 \times 10^{6}$ $\mathrm{S} \cdot \mathrm{m}^{-1}$ at $1073 \mathrm{~K}$ and $1123 \mathrm{~K}$, respectively, then decreases to $2.13 \times 10^{6} \mathrm{~S} \cdot \mathrm{m}^{-1}$ at $1173 \mathrm{~K}$; with the extending holding time, the electrical conductivity changes from $2.17 \times 10^{6}$ $\mathrm{S} \cdot \mathrm{m}^{-1}$ for $0 \mathrm{~min}$ to $2.21 \times 10^{6} \mathrm{~S} \cdot \mathrm{m}^{-1}$ for $10 \mathrm{~min}$, and finally declines to $2.10 \times 10^{6} \mathrm{~S} \cdot \mathrm{m}^{-1}$ for $30 \mathrm{~min}$. It is interesting to note that the electrical conductivity and shear strength change 
similarly with the brazing parameters, suggesting that the two properties might be driven by the same microstructure characteristics of the $\mathrm{Ti}_{2} \mathrm{AlC}$ joints.

In summary, the optimal brazing temperature and holding time in the present work have been determined to be $1123 \mathrm{~K}$ and $10 \mathrm{~min}$, respectively. The maximum shear strength of the $\mathrm{Ti}_{2} \mathrm{AlC}$ joints using the pure $\mathrm{Al}$ filler metal is measured to be $95 \mathrm{MPa}$, with the electrical conductivity of $2.21 \times 10^{6} \mathrm{~S} \cdot \mathrm{m}^{-1}$, accounts for $43 \%$ and $93 \%$ of the $\mathrm{Ti}_{2} \mathrm{AlC}$ substrate, respectively.

\subsection{Microstructure observation and phase characterization}

The morphologies of the $\mathrm{Ti}_{2} \mathrm{AlC}$ joints brazed at different temperatures are displayed in Fig. 3. In the diagrams, two phases with different morphologies can be observed in the filler area. Firstly, a phase with a light grey contrast is labeled $\mathrm{A}$ in the figure. It has a rod-like shape and it generally originates from the interaction surface. Secondly, a dark grey phase labeled B in the figure, makes up the major part of the filler area. The EDS results suggest that the elemental composition of the phase A is $\mathrm{Ti}_{24.2} \mathrm{Al}_{75.8}$ (in atomic percentage), and that of the phase $\mathrm{B}$ is $\mathrm{Ti}_{0.9} \mathrm{Al}_{99.1}$ (in atomic percentage). Therefore, the light grey phase $\mathrm{A}$ is suggested to be the $\mathrm{TiAl}_{3}$ intermetallic compound, while the dark grey phase B is supposed to correspond to the $\mathrm{Al}$ filler metal. It is worthwhile pointing that the formation of the $\mathrm{TiAl}_{3}$ intermetallic compound has also been discovered in the $\mathrm{Al}$ alloy/ $\mathrm{Ti}_{2} \mathrm{AlC}$ composites produced by infiltration of sponge of MAX phase with molten Al metal (or alloy) [18], in spite of the short infiltration time of approximately 30 seconds. Therefore, it is reasonable to suggest that 
the $\mathrm{Ti}_{2} \mathrm{AlC}$ ceramics can readily react with molten $\mathrm{Al}$ during the brazing process. The formation of the $\mathrm{TiAl}_{3}$ intermetallic compound can be explained by the equilibrium in the $\mathrm{Al}-\mathrm{C}$ - $\mathrm{Ti}$ phase diagram. Indeed a transformation of the $\mathrm{Ti}_{2} \mathrm{AlC}$ ceramics might occur under the presence of $\mathrm{Al}$. The following reactions can provide a source of $\mathrm{Ti}$ atoms according to:

$$
\begin{gathered}
2 \mathrm{Ti}_{2} \mathrm{AlC}+2 \mathrm{Al} \rightarrow \mathrm{Ti}_{3} \mathrm{AlC}_{2}+\mathrm{TiAl}_{3} \\
\mathrm{Ti}_{2} \mathrm{AlC}+2 \mathrm{Al} \rightarrow \mathrm{TiC}+\mathrm{TiAl}_{3}
\end{gathered}
$$

Both the two reactions are reasonable considering thermodynamic aspect, which has been verified by Witusiewicz et al [9], and the reaction products differ depending on the $\mathrm{Al}$ concentration and temperature. However, the other by-products of the reactions (1) and (2), either the $\mathrm{Ti}_{3} \mathrm{AlC}_{2}$ or the $\mathrm{TiC}_{\mathrm{x}}$ compound, are not observed in the $\mathrm{BSE}$ micrographs. It is worthwhile pointing out that the close average atomic number between $\mathrm{TiC}$ compound $\left(\bar{Z}_{\mathrm{TiC}}=14\right)$ and $\mathrm{Al}$ metal $\left(\bar{Z}_{\mathrm{Al}}=13\right)$, as well as that between $\mathrm{Ti}_{2} \mathrm{AlC}$ phase $\left(\bar{Z}_{\mathrm{Ti}_{2} \mathrm{AlC}}=15.75\right)$ and $\mathrm{Ti}_{3} \mathrm{AlC}_{2}$ phase $\left(\bar{Z}_{\mathrm{Ti}_{3} \mathrm{AlC}_{2}}=15.17\right)$ renders it difficult to discriminate these phases from BSE images. Therefore, the presence of these by-products should be investigated using other characterization techniques. Nevertheless, a microstructure evolution with the temperature can be evidenced from the micrographs. With the increasing temperature, an apparent rise in the content of the $\mathrm{TiAl}_{3}$ compound can be observed in the joints, which, again, may be attributed to the heavier decomposition degree of the $\mathrm{Ti}_{2} \mathrm{AlC}$ substrate. Therefore, the reinforced wetting and interaction process are considered to be the major factors contributing to the 
improved mechanical property of the $\mathrm{Ti}_{2} \mathrm{AlC}$ joints. In addition, the morphology of the $\mathrm{TiAl}_{3}$ compound changes as well: at low brazing temperature, the $\mathrm{TiAl}_{3}$ compound with low aspect ratio forms in the joints, originates from the wetting surface; while brazed at high temperature, the aspect ratio of the $\mathrm{TiAl}_{3}$ compound increases significantly, and the grains even cross the whole joint at $1173 \mathrm{~K}$. Since the $\mathrm{TiAl}_{3}$ intermetallic compound possesses poorer deformation ability than the Al metal filler, cracks may easily be initiated from the $\mathrm{TiAl}_{3}$ compound, which contributes to the declining shear strength of the $\mathrm{Ti}_{2} \mathrm{AlC}$ joints at $1173 \mathrm{~K}$. Furthermore, a measurement performed under the SEM suggests that the width of the $\mathrm{Ti}_{2} \mathrm{AlC}$ joints brazed at $1023 \mathrm{~K}, 1073 \mathrm{~K}$ and $1123 \mathrm{~K}$ are very close to each other, as they are determined to be $31.8 \mu \mathrm{m}, 34.4 \mu \mathrm{m}$ and $29.6 \mu \mathrm{m}$, respectively. However, when the brazing temperature reaches up to $1173 \mathrm{~K}$, the width remarkably reduces to $16.4 \mu \mathrm{m}$, which is considered to be another factor responsible for the poor mechanical property of the joints at high temperature.

Fig. 4 shows the morphology of the $\mathrm{Ti}_{2} \mathrm{AlC}$ joints brazed at $1123 \mathrm{~K}$, holding for 0 min and 30 min, respectively. It can be concluded from the figure that the extending holding time has similar effect on the microstructure evolution of the brazing joints with the increasing brazing temperature. When the holding time is $0 \mathrm{~min}$, the wetting process, as well as the interaction process is not sufficient. Therefore, a small amount of $\mathrm{TiAl}_{3}$ intermetallic compound with small aspect ratio forms on the interface. Afterwards, when the holding time prolongs, more $\mathrm{TiAl}_{3}$ compound can be observed in the joints and the shear strength remarkable improves, which is attributed to the reinforced 
interaction between $\mathrm{Ti}_{2} \mathrm{AlC}$ substrate and pure $\mathrm{Al}$ metal filler. In addition, the holding time is supposed to have more significant effect on the width of the $\mathrm{Ti}_{2} \mathrm{AlC}$ joints. It can be observed from the figures that the joints width remarkably decreases from $60.5 \mu \mathrm{m}$ to 29.6 $\mu \mathrm{m}$ when the holding time is extended from $0 \mathrm{~min}$ (Fig. 4(a)) to $10 \mathrm{~min}$ (Fig. 3(c)), and then further declines to $20.9 \mu \mathrm{m}$ for $30 \mathrm{~min}$ (Fig. 4(b)). The major factor responsible for the narrowing width of the $\mathrm{Ti}_{2} \mathrm{AlC}$ joints is assumed to be the squeezed out liquid $\mathrm{Al}$ filler during the brazing process, due to the improved wettability and fluidity with extending holding time, which is verified by the macro morphology observation. According to the conclusion above, the decreasing width of the joints would lead to an increase of the relative fraction of the $\mathrm{TiAl}_{3}$ intermetallic compound in the $\mathrm{Ti}_{2} \mathrm{AlC}$ joints, which is considered to be unfavorable for the mechanical property. Correspondingly, the shear strength declines to a low level when the holding time is $30 \mathrm{~min}$.

The pure Al metal filler adopted in the present work is considered to be favorable for restraining the outward-diffusion of $\mathrm{Al}$ atoms in the $\mathrm{Ti}_{2} \mathrm{AlC}$ structure, thereby preventing the transformation of the ceramic substrate. However, a small amount of decomposition products can still be observed in the $\mathrm{Ti}_{2} \mathrm{AlC}$ joint. In order to determine the reaction products in the joints, thereby revealing the decomposition mechanisms of the $\mathrm{Ti}_{2} \mathrm{AlC}$ ceramic during the brazing process, some supplementary characterizations were performed. According to the reaction (1), the increasing Al content in the substrate would contribute to the transformation of the $\mathrm{Ti}_{2} \mathrm{AlC}$ phase to the $\mathrm{Ti}_{3} \mathrm{AlC}_{2}$ phase, accompanied with the formation of the $\mathrm{TiAl}_{3}$ intermetallic compound. Therefore, the 
reaction product $\mathrm{Ti}_{3} \mathrm{AlC}_{2}$ might distribute in the $\mathrm{Ti}_{2} \mathrm{AlC}$ substrate if the reaction proceeds following the equation (1). An EDS line scan was carried out across the joining interface, and the results are displayed in Fig. 5. Fig. 5(a) shows the magnified morphology of the interaction area in the $\mathrm{Ti}_{2} \mathrm{AlC}$ brazing joints. It is worthwhile pointing out that the grain boundary of the $\mathrm{Ti}_{2} \mathrm{AlC}$ ceramic can be apparently observed in the interaction area, which is mainly attributed to the diffusion of the Al filler into the ceramic substrate along the grain boundary. In addition, the yellow line in the figure illustrates the scanning path, and the corresponding EDS line scan result is shown in Fig. 5(b). It can be concluded from the figure that an inter-diffusion layer with a thickness of $2.6 \mu \mathrm{m}$ forms in the interaction area (the corresponding position is labeled in the Fig. 5(a)), in which the Ti atoms diffuses into the brazing filler while the $\mathrm{Al}$ atoms diffuses into the ceramic substrate. The outward-diffusing Ti atoms can be rapidly consumed by reacting with the $\mathrm{Al}$ filler metal, and then forms the $\mathrm{TiAl}_{3}$ intermetallic compound which nucleates on the interface because of the small temperature gradient. Meanwhile, the $\mathrm{Al}$ atoms diffuse into the $\mathrm{Ti}_{2} \mathrm{AlC}$ substrate since the pure $\mathrm{Al}$ metal filler possesses higher $\mathrm{Al}$ concentration. However, the $\mathrm{Al}$ content of the $\mathrm{Ti}_{2} \mathrm{AlC}$ substrate in the interaction area remains unchanged according to the EDS results. Considering the morphology observation in Fig. 5(a), it is reasonable to suppose that the inward-diffusion $\mathrm{Al}$ atoms mainly distribute on the grain boundary of the $\mathrm{Ti}_{2} \mathrm{AlC}$ ceramic, and would not lead to the transformation from $\mathrm{Ti}_{2} \mathrm{AlC}$ phase to $\mathrm{Ti}_{3} \mathrm{AlC}_{2}$ phase. Although it is difficult to characterize the phases in the inter-diffusion layer accurately 
using the SEM and XRD techniques, the formation of such a thin layer would not be the major factor responsible for large quantities of the $\mathrm{TiAl}_{3}$ compound in the joints. According to the reaction (2), part of the $\mathrm{Ti}_{2} \mathrm{AlC}$ substrate would decompose during the brazing process, and then forms the $\mathrm{TiAl}_{3}$ and $\mathrm{TiC}_{\mathrm{x}}$ compounds. In general, the $\mathrm{TiC}_{\mathrm{x}}$ phase with nanolaminate microstructure can be dissolved by the liquid filler, therefore, the reaction product $\mathrm{TiC}_{\mathrm{x}}$ might be able to be found in the filler area if the reaction proceeds following the equation (2). Afterwards, an XRD analysis of the brazing joints was performed in the following way: the $\mathrm{Ti}_{2} \mathrm{AlC}$ brazing couple was cut along one of the substrate sides and then cautiously ground until the joint was exposed. The corresponding XRD pattern is displayed in Fig. 5. It can be observed from the diagram that the $\mathrm{Al}$ filler metal is the major phase in the $\mathrm{Ti}_{2} \mathrm{AlC}$ joints. In addition, the $\mathrm{TiC}_{\mathrm{x}}$ compound, as well as the $\mathrm{TiAl}_{3}$ intermetallic compound is detected, suggesting that the decomposition of $\mathrm{Ti}_{2} \mathrm{AlC}$ substrate during the brazing process contributes to the formation of $\mathrm{TiAl}_{3}$ and $\mathrm{TiC}_{\mathrm{x}}$ compounds, following the reaction (2).

\section{Conclusions}

In the present work, joining of the $\mathrm{Ti}_{2} \mathrm{AlC}$ ceramics has been successfully performed using the pure $\mathrm{Al}$ filler metal, at the brazing temperature of $1023 \mathrm{~K}, 1073 \mathrm{~K}$, $1123 \mathrm{~K}$ and $1173 \mathrm{~K}$, holding for $0 \mathrm{~min}, 10 \mathrm{~min}$ and 30min, respectively. The results lead to the following conclusions:

(1). The maximum shear strength of the $\mathrm{Ti}_{2} \mathrm{AlC}$ joints brazed using the pure $\mathrm{Al}$ filler metal is measured to be $95 \mathrm{MPa}$, together with an electrical conductivity of 
$2.21 \times 10^{6} \mathrm{~S} \cdot \mathrm{m}^{-1}$. This optimal characteristic is obtained at the brazing temperature of $1123 \mathrm{~K}$ and holding for $10 \mathrm{~min}$. The shear strength of the brazing joints accounts for $43 \%$ of the shear strength of the $\mathrm{Ti}_{2} \mathrm{AlC}$ substrate, while the electrical conductivity accounts for $93 \%$.

(2). During the brazing process, an inter-diffusion layer forms in the $\mathrm{Ti}_{2} \mathrm{AlC}$ substrate, in which the $\mathrm{Ti}$ atoms diffuses into the brazing filler while the $\mathrm{Al}$ atoms diffuses into the ceramic substrate. The outward-diffusing Ti atoms can be rapidly consumed by forming the $\mathrm{TiAl}_{3}$ compound in the joints, while the inward-diffusing $\mathrm{Al}$ atoms, however, mainly distribute on the grain boundary of the $\mathrm{Ti}_{2} \mathrm{AlC}$ substrate.

(3). Since the outward-diffusion of $\mathrm{Al}$ atoms in the $\mathrm{Ti}_{2} \mathrm{AlC}$ structure has been restrained by utilizing the brazing filler with high Al content, only a small amount decomposition products, including the $\mathrm{TiAl}_{3}$ and $\mathrm{TiC}_{\mathrm{x}}$ compounds can still be observed in the $\mathrm{Ti}_{2} \mathrm{AlC}$ joint. The weak interaction between $\mathrm{Ti}_{2} \mathrm{AlC}$ ceramic and pure $\mathrm{Al}$ filler is considered to be favorable for restraining the thermal stability of the $\mathrm{Ti}_{2} \mathrm{AlC}$ brazing joints.

\section{Acknowledgement}

This work was financially supported by the National Natural Science Foundation of China (NSFC) under Grant Nos. 51372049, 51621091 and U1537206. The authors gratefully acknowledge the financial support from the China Scholarship Council (CSC).

\section{Reference}


[1] M.W. Barsoum, The $\mathrm{M}_{n+1} \mathrm{AX}_{n}$ phases: a new class of solids; thermodynamically stable nanolaminates, Prog. Solid State Chem. 28 (1-4) (2000) 201-281.

[2] M. Radovic, M.W. Barsoum, MAX phases: bridging the gap between metals and ceramics, Am. Ceram. Soc. Bull. 92 (3) (2013) 20-27.

[3] Z.M. Sun, Progress in research and development on MAX phases: a family of layered ternary compounds, Int. Mater. Rev. 56 (3) (2011) 143-166.

[4] Y.L. Bai, X.D. He, C.C. Zhu, G.Q. Chen, Microstructures, Electrical, Thermal, and Mechanical Properties of Bulk $\mathrm{Ti}_{2} \mathrm{AlC}$ Synthesized by Self-Propagating High-Temperature Combustion Synthesis with Pseudo Hot Isostatic Pressing, Journal Of the American Ceramic Society 95 (1) (2012) 358-364.

[5] S. Gupta, D. Filimonov, T. Palanisamy, M.W. Barsoum, Tribological behavior of select MAX phases against $\mathrm{Al}_{2} \mathrm{O}_{3}$ at elevated temperatures, Wear 265 (3-4) (2008) $560-565$.

[6] T. Thomas, C.R. Bowen, Thermodynamic predictions for the manufacture of $\mathrm{Ti}_{2} \mathrm{AlC}$ MAX-phase ceramic by combustion synthesis, J. Alloy. Compd. 602 (2014) 72-77.

[7] S.R. Kulkarni, A. Wu, Synthesis of $\mathrm{Ti}_{2} \mathrm{AlC}$ by spark plasma sintering of TiAl-carbon nanotube powder mixture, J. Alloy. Compd. 490 (1-2) (2010) 155-159.

[8] T. Thomas, C.R. Bowen, Effect of particle size on the formation of $\mathrm{Ti}_{2} \mathrm{AlC}$ using combustion synthesis, Ceram. Int. 42 (3) (2016) 4150-4157.

[9] V.T. Witusiewicz, B. Hallstedt, A.A. Bondar, U. Hecht, S.V. Sleptsov, T.Y. Velikanova, Thermodynamic description of the Al-C-Ti system, J. Alloy. Compd. 623 
(2015) 480-496.

[10] A. Ganguly, M.W. Barsoum, R.D. Doherty, Interdiffusion between $\mathrm{Ti}_{3} \mathrm{SiC}_{2}-\mathrm{Ti}_{3} \mathrm{GeC}_{2}$ and $\mathrm{Ti}_{2} \mathrm{AlC}-\mathrm{Nb}_{2} \mathrm{AlC}$ diffusion couples, Journal of the American Ceramic Society 90 (7) (2007) 2200-2204.

[11] X.H. Yin, M.S. Li, T.P. Li, Y.C. Zhou, Diffusion bonding of $\mathrm{Ti}_{3} \mathrm{AlC}_{2}$ ceramic via a Si interlayer, Journal of Materials Science 42 (17) (2007) 7081-7085.

[12] W.K. Pang, I.M. Low, B.H. O'Connor, A.J. Studer, V.K. Peterson, Z.M. Sun, J.P. Palmquist, Iop, Comparison of thermal stability in MAX 211 and 312 phases, International Conference on Neutron Scattering $2009251 \quad$ (2010) 4.

[13] G.C. Wang, G.H. Fan, J. Zhang, T.P. Wang, X.W. Liu, Microstructure evolution and brazing mechanism of $\mathrm{Ti}_{2} \mathrm{AlC}-\mathrm{T}_{2} \mathrm{AlC}$ joint by using pure-silver filler metal, Ceram. Int. 41 (6) (2015) 8203-8210.

[14] C. Lu, G. Wang, G. Yang, G. Fan, J. Zhang, X. Liu, Substitution Behavior of Ag Atoms in the $\mathrm{Ti}_{2} \mathrm{AlC}$ Ceramic, Journal of the American Ceramic Society (2016).

[15] W.K. Pang, I.M. Low, B.H. O'Connor, V.K. Peterson, A.J. Studer, J.P. Palmquist, In situ diffraction study of thermal decomposition in Maxthal $\mathrm{Ti}_{2} \mathrm{AlC}$, J. Alloy. Compd. 509 (1) (2011) 172-176.

[16] C. Lu, J. Zhang, T. Duan, C. Liu, Microstructure evolution and brazing mechanisms of the $\mathrm{Ti}_{2} \mathrm{AlC} / \mathrm{Ni}$ joints using nickel based filler alloy, Journal of the European Ceramic Society (2016).

[17] M.W. Barsoum, M. Ali, T. El-Raghy, Processing and characterization of $\mathrm{Ti}_{2} \mathrm{AlC}$, 
$\mathrm{Ti}_{2} \mathrm{AlN}$, and $\mathrm{Ti}_{2} \mathrm{AlC}_{0.5} \mathrm{~N}_{0.5}$, Metall. Mater. Trans. A-Phys. Metall. Mater. Sci. 31 (7) (2000) 1857-1865.

[18] L. Hu, M. O’Neil, V. Erturun, R. Benitez, G. Proust, I. Karaman, M. Radovic, High-Performance Metal/Carbide Composites with Far-From-Equilibrium Compositions and Controlled Microstructures, Sci Rep 6 (2016). 

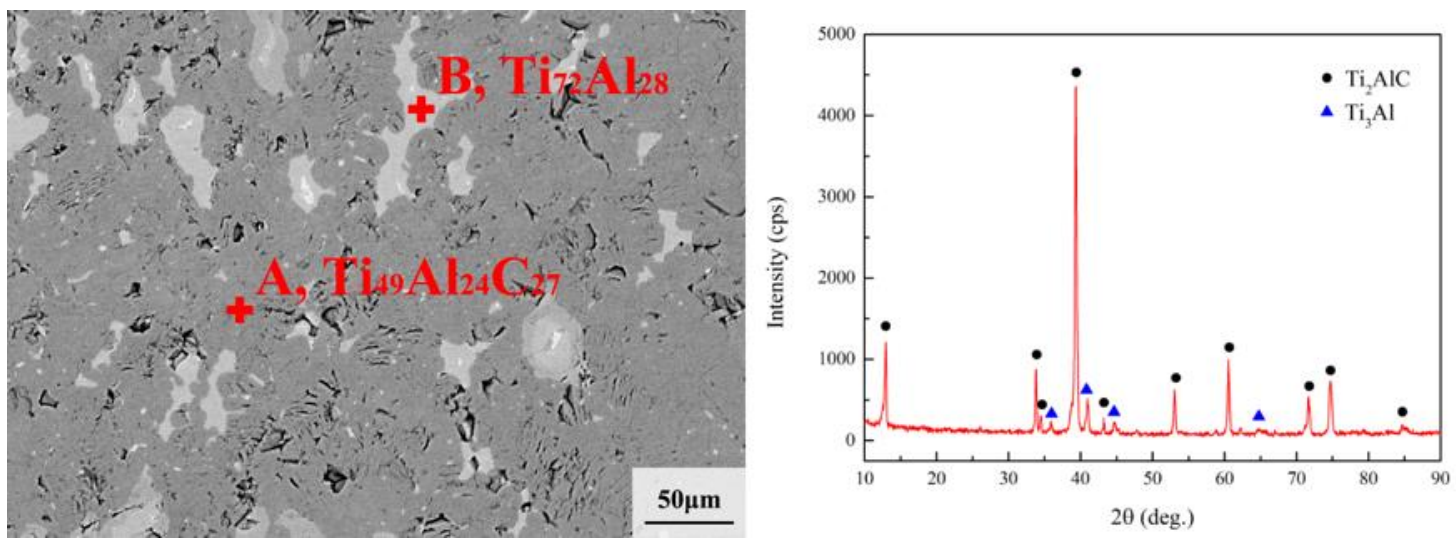

Fig. 1. Characterization of the raw $\mathrm{Ti}_{2} \mathrm{AlC}$ ceramics: (a). The BSE morphology; (b). The XRD pattern. 

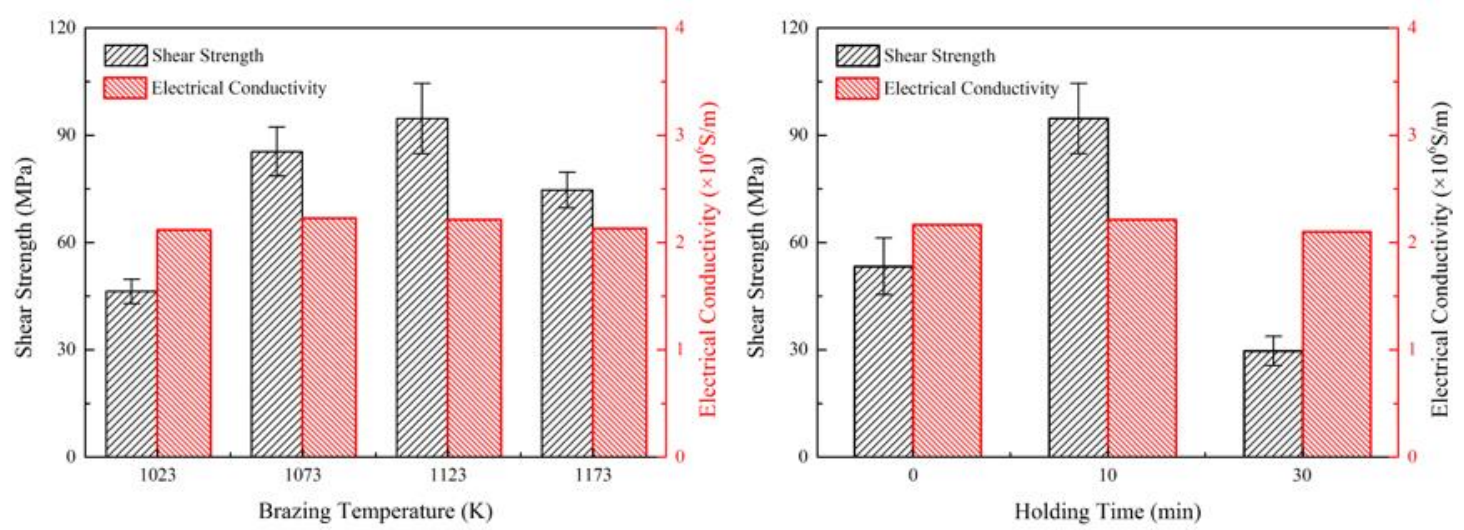

Fig. 2. The shear strength and electrical conductivity of the $\mathrm{Ti}_{2} \mathrm{AlC}$ joints: (a) achieved with different brazing temperature; (b) achieved with different holding time. 


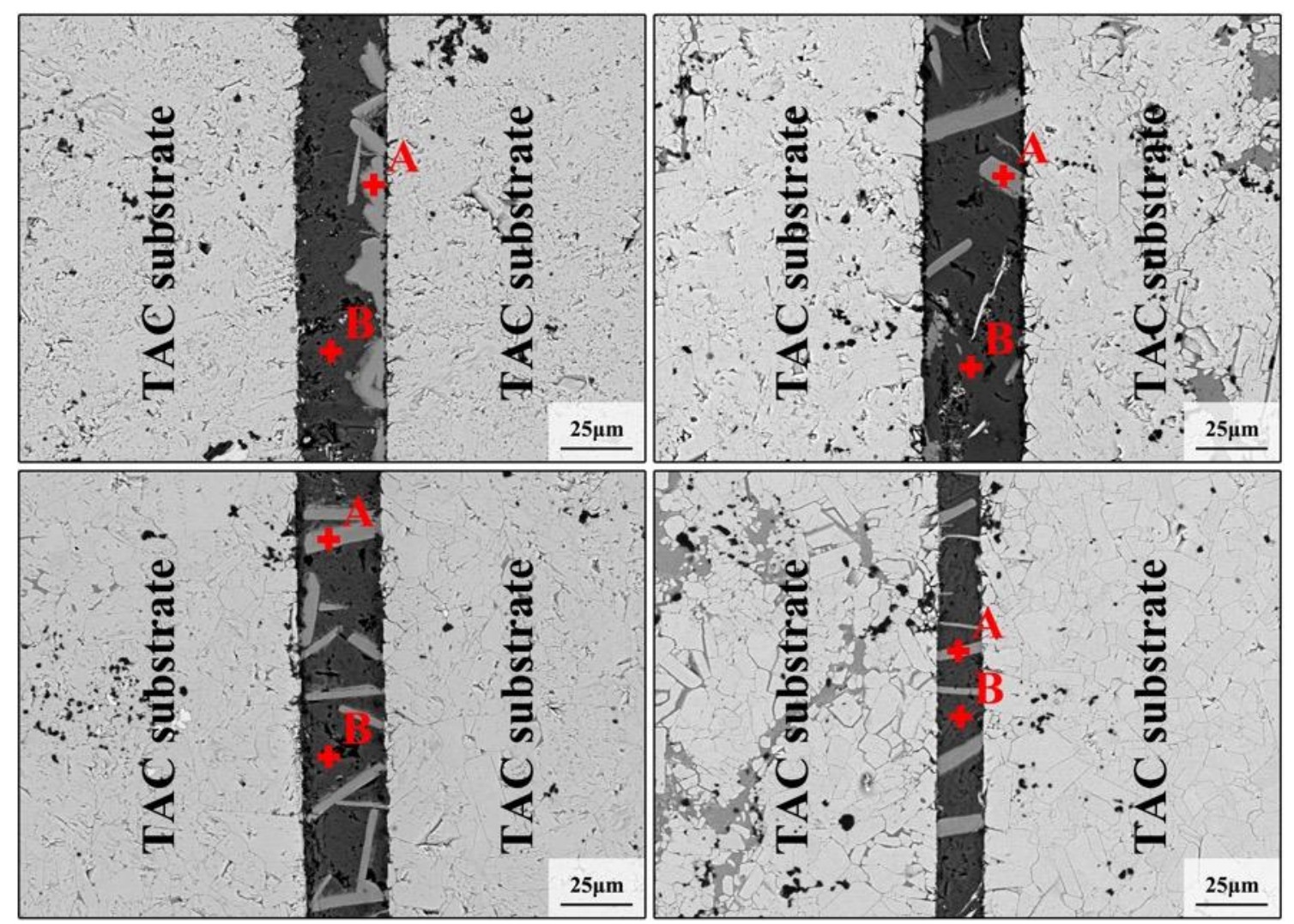

Fig. 3. The microstructure of the $\mathrm{Ti}_{2} \mathrm{AlC}$ joints, brazed at (a). $1023 \mathrm{~K}$; (b). $1073 \mathrm{~K}$; (c).

$1123 \mathrm{~K}$ and (d). $1173 \mathrm{~K}$, respectively. 


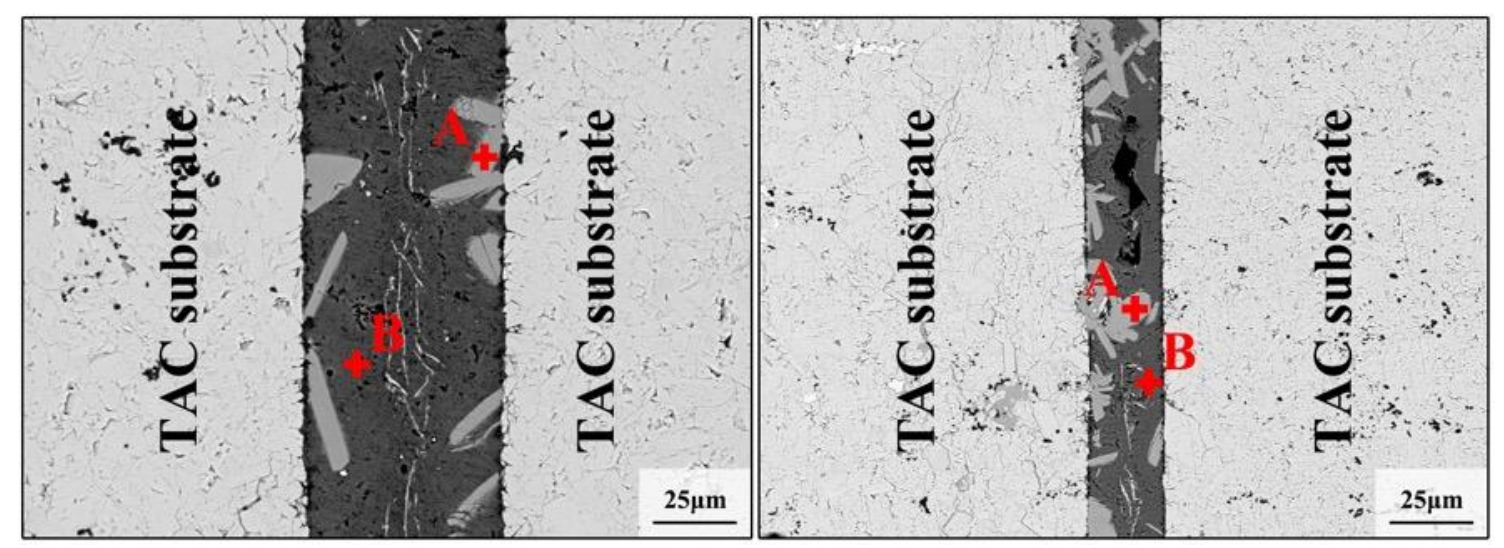

Fig. 4. The microstructure of the $\mathrm{Ti}_{2} \mathrm{AlC}$ brazing joints holding for (a). 0 min and (b). 30 min, respectively. 

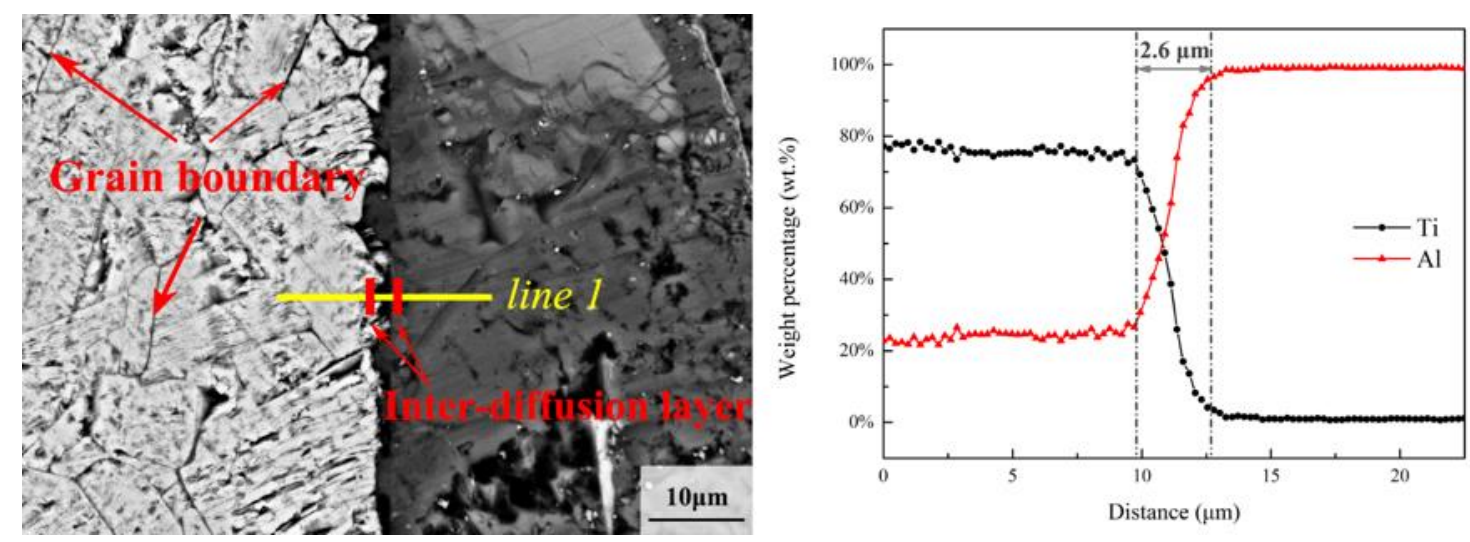

Fig. 5. The EDS line scanning results across the interaction area: (a). The BSE morphology of the interaction area, together with the EDS line scanning path; (b). The EDS line scanning results. 


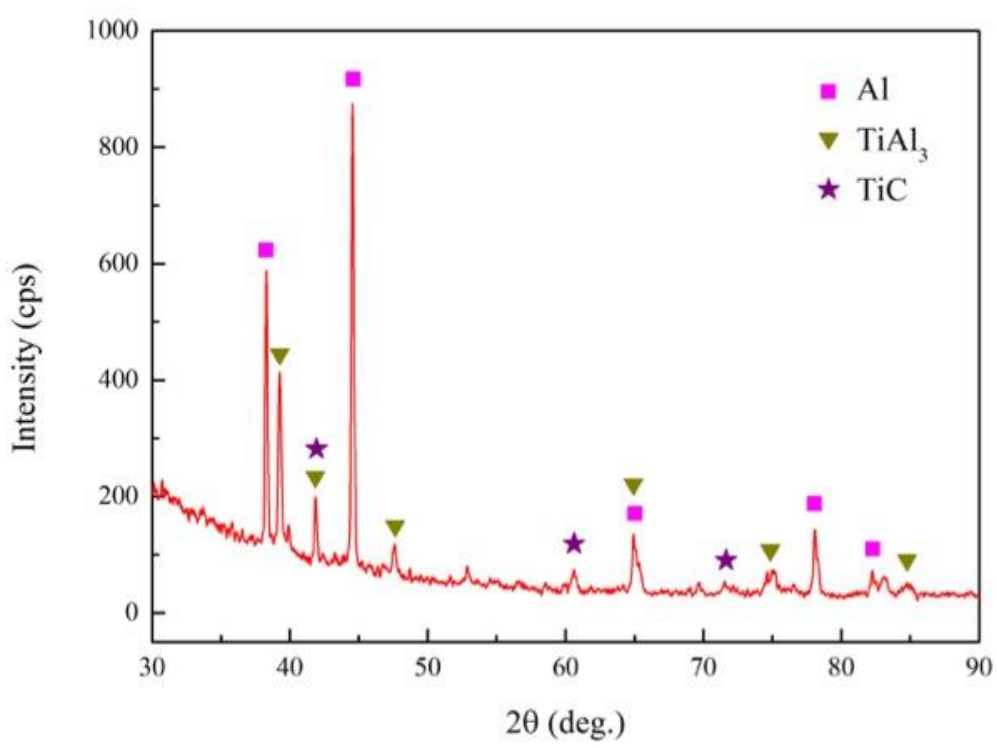

Fig. 6. The XRD pattern collected in the filler area of the $\mathrm{Ti}_{2} \mathrm{AlC}$ brazing joints. 